\title{
POLINA KHMILEVSKA
}

DOI : 10.14746/rie.2021.15.15

Krakowska Akademia im. Andrzeja Frycza Modrzewskiego

ORCID: 0000-0001-8434-8116

\section{The structure of the Eurosceptic movement in Poland - political and civil far-right extremists}

\section{Introduction}

During last decade we have seen the global political vector inclining towards right conservative powers, causing the chain of astonishing political decisions and events. The most obvious examples are Britain's decision of Brexit, President Trump elections in the US and Eurosceptic stream of countries among the EU member states. Currently Poland is one of the most Eurosceptic member states in the EU together with Czech Republic and Hungary, which also share the common nationalistic and conservative values.

Euroscepticism may be defined as skeptical or negative perception of the European Union or of the process of the European integration. The concept does not have a long history and has a journalistic origin, having such synonyms as Europhobia, Eurocyinism or Europessimism (Rodríguez-Aguilera de Prat, 2013, p. 21). In the political science Euroscepticism was used and formulated for the first time in 1998 by British scholars Paul Taggart and Aleks Szczerbiak. They argued that there is a distinction between hard and soft Euroscepticism: first denies European integration as such and the second one relates to the negative attitude towards some or all EU policies. Namely, hard Euroscepticism, "a principled opposition to the EU and European integration and therefore can be seen in parties who think that their counties should withdraw from membership, or whose policies towards the EU are tantamount to being opposed to the whole project of European integration as it is currently conceived". Soft Euroscepticism "is NOT a principled objection to European integration or EU membership but where concerns on one (or a number) of policy areas lead to the expression of qualified opposition to the EU, or where there is a sense that national interest is currently at odds with the EU's trajectory" (Taggart, Szczerbiak, 2002, p. 4).

For the wider audiences Poland's shift to the right became distinct and bold after 2015, when right-wing populist party Law and Justice (Prawo i Sprawiedliwość, PiS) came to the power. However, this is the result of gradual polarization of the Polish society and accumulation of the tensions inside of it. Among the actual causes are frustration over neoliberal politics, economic stagnation, national identity crisis, etc. What is more, the extreme right groups have always been present in Polish politics and society, and even can be considered as an element of the cultural and national identity together with strong national dignity and Catholic church patronage (Pankowski, 2010, pp. 10-11). 
During the Communist era these groups were somehow oppressed, but in covert way, since Soviet government actually was using the nationalistic and patriotic agenda to shift public attention from the stagnating economy. When in 1989 Poland finally snatched its independence from the USSR, central public opinion was aimed at European Integration, as it was the only way to get rid of Soviet and later Russian influence, as well as to re-build the economy of the country. During this period even though such groups and opinions existed, then were not getting much attention or support, which lasted until the Polish radical right entered into a phase of its intensification and radicalization after the parliamentary elections in 2001 (Płatek, Płucienniczak, 2017, pp. 286-313).

The aim of this article is to analyze the far-right social and political movements, considering them as the main thruster of the Euroscepticism in Poland. With this regards the brief examination of the state of these movements is needed upon gaining independence till the EU association, and then will focus on the far-right extremist movement since 2007 up until now. Moreover, two dimensions will be studied - civil society groups like civil organizations and movements, as well as political - political parties and blocs.

The main questions are how right-wing extremism looks like in Poland and how it developed over the time? What are the main civil and political actors? Which part of the society engage or support the movement and who are these people? What is the connection and cooperation between far-right political and social groups? That will give us an idea on what are the future prospects of the Polish political vector and whether Polexit is possible.

For the research several methodologies have been used, such as legal and institutional, but mainly empirical - observation and description, including analysis, synthesis, classification, induction and deduction. Also, some of the data have been analyzed from the statistical and systematic perspective. Different kinds of resources have been applied such as documents, academic monographs and papers.

\section{Roots of Euroscepticism in Poland - rise of right-wing extremists since joining the European integration}

Since the right-wing extremist groups will be viewed as the main source of Euroscepticism in Poland, we should outline what these mean and what are their opposites. Politically right-wing extremist parties are clustered into one separate party family on the bases of ideology, origin, transnational federations, policies, etc. In essence, there is no consensus on the exact definition of the term itself. Yet, majority agrees that the term meaning includes several core distinct features: racism, xenophobia, nationalism, often described as anti-democratic and ethnocentric. Other features also might include anti-communism, anti-parliamentarianism, anti-pluralism, militarism, law-and-order thinking, a demand for astrong political leader and/or executive, anti-Americanism and cultural pessimism (Mudde, 2000, pp. 10-12).

Another key element of the political movement in Poland is that it has also populist facets as it is a frequently occurring pairing. The notion of populism is vague and 
includes many aspects like anti-elitism and perception of the society as a confrontation between the people and elites (Mudde, 2004, pp. 12-13); 'tends to simplify political issues, dichotomizingthem into black and white and calling for yes or no answers'; exploitation of the term 'democracy' in a very literal and direct way - so that power be placed in the unfettered hands of the people. Additionally, populis m can be customized, as it often referred to as the politics of resentment and due to that always opposes the existing order with the popular slogans and theses (Golder, 2016, p. 479).

Historically far-right's main opponents have been the Left, but nowadays they oppose neoliberalism, globalism, universal human right protection and pluralism. In some cases, extreme-right is perceived as a collective term for all 'progress-hostile forces' and that is where we can place such characteristics as promotion of the traditional values and rejection of new or 'foreign' ones in terms of condemnation of LGBTQ community, deprivation of women the right of abortion, etc.

Another important issue is the phenomenon of civil society in the context of farright extremist discourse. As the civil society itself is traditionally considered to be a part of the liberal-democratic values, in case of the movement that opposes the later mentioned ideology should be then called 'uncivil society'. Nevertheless, such organizations are considered to be a part of the civil society, as it has been proven, that not always civil society contributes to the strengthening of the liberal democratic order and it is institutions that do it. Civil society in this case just gives the opportunity to the masses to express the opinions and influence the institutions (Cipek, Laskovic, 2019, pp. 157-158).

The important background is that far-right movement associated with Eurosceptic views emerged since the initial debate inside of the Polish society started upon gaining its independence in 1989. Despite the Polish national identity has not been attenuated as of other former Soviet republics, Poland as a state still had to go through the learning curve. After long period under the USSR oppression, people aspired for something that would be totally opposite and radical to what they have suffered from last forty years. The direction to the West seemed to be most promising and perspective. However, the path of the liberal democracy with all the features of globalization and free market economy were definitely beneficial for the more educated upper-middle class, while depriving low-skilled workers, who actually did not have a chance to experience all the advantages of the new regime.

Yet, extremist far-right groups were generally marginal and not that active in the landscape of the civil action up until 2006-2007, which is explained by several theories. Firstly, 'grievance theory' represented by David Ost (2006) - it says that Polish society was broken and has turned radically towards the right because social democrats accepted neoliberal social politics that killed social equality and justice. The focus of the 'grievance theory' is the claim that the radical right emerges in the absence of the Left (Cipek, Laskovic, 2019, pp. 156-157).

Secondly, is a 'opportunity structure theory' that has been put forward by Platek and Plucienniczak, which actually tackles the cause of inactivity of far-right in first decade of independence. It says, that the rise of the radical right in Poland was not the result of the economic crisis, but their ability to become part of civil society and to impose their agenda in public (Płatek, Płucienniczak, 2017, pp. 286-313). Anyway, 
the truth is somewhere in between, as all the factors take place in the reality and it is rather the combination of both that resulted into it.

The first period until 2000 is called by Płatek and Płucienniczak (2017) the marginalization stage, when mobilization and participation are low, the organizational structures are weak and unable to produce the political power. During that time the movement was not represented in the parliament and carried their activities on the civil society landscape. The Polish National Community (Polska Wspólnota Narodowa) has been the only visible organization, that was registered as a political party, but its activities and organizational structures resembled a youth gang consisting of skinheads (Płatek, Płucienniczak, 2017). Antisemitic movements has been the central topic for the far-right nationalistic movements, which was not deliberately fact-based, but rather Jews were chosen to be an alienated group that the hatred could be placed upon.

During that period the protests of the subcultures has been particularly confrontational and violent and often included acts of violence from injuries to murders during uncoordinated actions against 'enemies' who accidentally ran into aggressive small gangs of skinheads. Consequently, the victims mainly were of ethnic minorities and leftists. The other share of notable share of demonstrative and conventional actions have been coordinated by the political movement (Płatek, Płucienniczak, 2016, pp. 134-135).

The second Institutionalization Phase starts around years 2000-2001 and is marked by the parliamentary elections. The political party the League of Polish Families (Liga Polskich Rodzin) received the opportunity to win thirty-eight seats in the Polish parliament and was a coalition of various conservative and nationalistic groups. Interestingly enough, at that time Polish political landscape was extremely supportive of the European integration and even biggest conservative party PiS was optimistic about the EU and upcoming referendum. However, the far-right movements reflected the growing uncertainty and fears in the society related to the future EU accession, as EU was "negative, emotional judgments expressing fears of the loss of sovereignty, of Poland's submission to foreign capital, threat of the enslavement of the Poles and turning them into a cheap labour force" (Płatek, Płucienniczak, 2016, pp. 137-138). In 2000, the number of opponents of the EU was almost equal to the number of its supporters, 29\% to $30 \%$ (CBOS VII, 2000). However, this ratio have changed as the referendum was coming due to the massive pro-EU campaign and in 2004 the number of Eurosceptics dropped to $18 \%$, but the again rose to $31 \%$ (CBOS III, 2004).

The growing share of the organizational structures, that distanced themselves from skinheads and other aggressive groups, were accountable for the conventional civil actions: appeals, conferences, open letters, legislative initiatives, and lawsuits (Płatek, Płucienniczak, 2017, pp. 301-302). Generally, LPR were moderate in the parliament and rarely confronted such issues as sexual and ethnic minorities, as targets associated with the previous period were actively discouraged by dedicated activists, as they could do more harm than good to the formalised movement (Płatek, Płucienniczak, 2016, pp. 138-139).

After the next parliamentary elections of 2005, during the Phase of Radicalization (2006-2013) the conservative right-wing Law and Justice (PiS) gains thirty-four seats and obtains the control over the power. Throughout this period the movement faces 


\begin{tabular}{|c|c|c|c|c|c|c|c|c|c|c|c|c|c|c|}
\hline \multirow{3}{*}{ 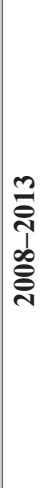 } & ن & & $\begin{array}{l}\stackrel{*}{*} \\
\stackrel{*}{\infty} \\
\stackrel{9}{+}\end{array}$ & $\begin{array}{l}* \\
* \\
\stackrel{*}{*} \\
\stackrel{1}{1}\end{array}$ & 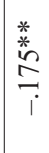 & & $\stackrel{*}{\stackrel{*}{\circ}}$ & है & 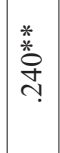 & $\stackrel{*}{*}$ & 苫 & 80 & 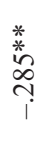 & $\begin{array}{l}\hat{\infty} \\
\| \\
z\end{array}$ \\
\hline & 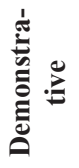 & & 苂 & $\stackrel{*}{*}$ & $\stackrel{\stackrel{*}{*}}{\stackrel{*}{\sim}}$ & & $\stackrel{\stackrel{*}{*}}{\underset{J}{ \pm}}$ & ป్ & $\mid \begin{array}{l}* \\
\stackrel{*}{*} \\
\stackrel{*}{0} \\
\stackrel{1}{i} \\
i\end{array}$ & $\stackrel{*}{\stackrel{*}{*}} \underset{:}{\stackrel{*}{I}}$ & 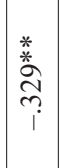 & $\begin{array}{l}* \\
\stackrel{*}{*} \\
\stackrel{\infty}{+} \\
\stackrel{+}{+}\end{array}$ & $\begin{array}{l}\text { *.* } \\
\stackrel{*}{0} \\
\stackrel{n}{n}\end{array}$ & $\begin{array}{l}0 \\
\infty \\
\text { Z }\end{array}$ \\
\hline & 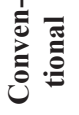 & & $\exists$ & $\frac{m}{\sigma}$ & $\stackrel{*}{\infty} \underset{+}{+}$ & & \& & $\widehat{\cong}$ & $\hat{\sigma}$ & $\begin{array}{l}0 \\
0 \\
0 \\
i\end{array}$ & $\underset{i}{\stackrel{f}{0}}$ & $\begin{array}{l}\infty \\
8 \\
1 \\
1\end{array}$ & $\stackrel{\infty}{\widetilde{\delta}}$ & $\tilde{N}$ \\
\hline \multirow{3}{*}{ 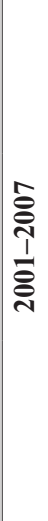 } & 莺 & & $\frac{\stackrel{*}{*}}{\stackrel{*}{\forall}}$ & $\hat{\mathrm{g}}$ & \begin{tabular}{l}
$*$ \\
\multirow{*}{*}{} \\
$\stackrel{0}{0}$ \\
$?$ \\
1
\end{tabular} & & $\begin{array}{l}\vdots \\
\vdots \\
\\
1 \\
1\end{array}$ & $\stackrel{*}{\stackrel{*}{c}}$ & $\stackrel{*}{\stackrel{*}{0}}$ & 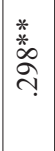 & 菜 & $\stackrel{*}{\stackrel{*}{0}}$ & है & $\begin{array}{l}\tilde{N} \\
\mathbb{Z} \\
\underline{Z}\end{array}$ \\
\hline & 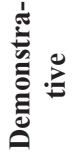 & & $\begin{array}{l}* \\
* \\
\stackrel{*}{*} \\
\stackrel{+}{\circ}\end{array}$ & $\stackrel{*}{\stackrel{*}{*}} \stackrel{\text { ک }}{\leftrightharpoons}$ & $\stackrel{*}{\stackrel{0}{0}}$ & & 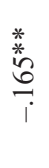 & 菳 & $\begin{array}{l}\overrightarrow{8} \\
i\end{array}$ & 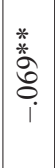 & 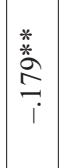 & 蒡 & ถิ & $\stackrel{n}{m}$ \\
\hline & & & 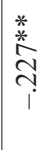 & $\frac{*}{*}$ & 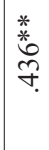 & & $\frac{*}{*}$ & \begin{tabular}{l}
$\stackrel{*}{*}$ \\
$\stackrel{*}{\infty}$ \\
\hdashline
\end{tabular} & 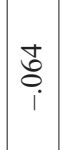 & $\begin{array}{l}\frac{*}{*} \\
\frac{\infty}{\infty} \\
! \\
\end{array}$ & 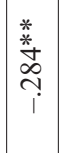 & 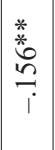 & $\hat{8}$ & $\begin{array}{l}\frac{6}{6} \\
\frac{11}{z}\end{array}$ \\
\hline \multirow{4}{*}{ 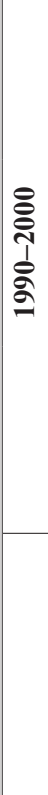 } & 胥 & & $\begin{array}{l}\stackrel{*}{*} \\
\stackrel{*}{6} \\
\sigma\end{array}$ & 荽 & 1 & & 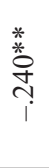 & $\begin{array}{l}0 \\
\$ \\
0 \\
i\end{array}$ & $\begin{array}{l}* \\
\stackrel{*}{*} \\
\stackrel{2}{7} \\
\gamma \\
\end{array}$ & 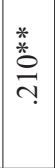 & I & 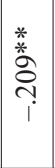 & $\begin{array}{l}\stackrel{*}{*} \\
\stackrel{\infty}{ \pm} \\
\end{array}$ & $\frac{g}{I}$ \\
\hline & 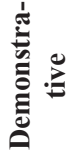 & & i. & $\frac{*}{*}$ & 1 & & $\stackrel{*}{\stackrel{*}{\cong}}$ & $\stackrel{*}{*}$ & $\mid \begin{array}{c}\stackrel{*}{*} \\
\stackrel{*}{\tilde{f}} \\
\stackrel{i}{i}\end{array}$ & $\frac{*}{*}$ & 1 & 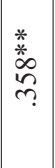 & $\stackrel{0}{5}$ & I \\
\hline & 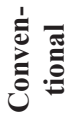 & & 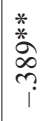 & $\begin{array}{l}\stackrel{*}{*} \\
\stackrel{*}{\sim} \\
\text { ?. }\end{array}$ & 1 & & $\begin{array}{l}\stackrel{*}{*} \\
\stackrel{*}{+} \\
n\end{array}$ & \&े & 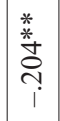 & 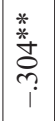 & 1 & $\overrightarrow{\widehat{a}}$ & $\stackrel{\Xi}{\stackrel{亠}{\sigma}}$ & $\begin{array}{l}\infty \\
0 \\
\text { I } \\
z\end{array}$ \\
\hline & & 范 & 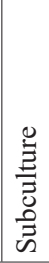 & 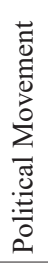 & 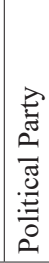 & 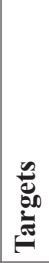 & 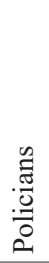 & $\begin{array}{l}.0 \\
\tilde{z} \\
0 \\
0 \\
0 \\
0 \\
0 \\
0 \\
0 \\
0 \\
0 \\
0\end{array}$ & 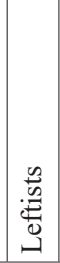 & 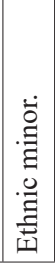 & 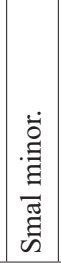 & 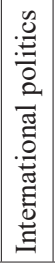 & 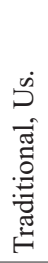 & \\
\hline
\end{tabular}


the oppression from the police and national security structures, but their 'traditional values' rhetoric is met with the enthusiasm from the Polish society. In 2008, 66 percent of Poles were against demonstrations of LGBT groups, and 76 percent were against formalization of same-sex marriages. In 2013, 83 percent of those surveyed considered homosexuality a deviation and 26 percent of them stated that it should not be accepted in Poland at all (Płatek, Płucienniczak, 2016, pp. 139-140).

Organizations, that reactivated during this period are the National-Radical Camp and National Rebirth of Poland (Narodowe Odrodzenie Polski), where the last one is the only organization in Poland openly expressing racist ideology. At this time, the events are predominantly initiated by the political movement and not by the political parties, although the confrontational type of actions initiated by the subculture have risen (Płatek, Płucienniczak, 2016, pp. 303-305). The marches organized by All-Polish Youth (MW) and the National-Radical Camp (ONR) in 2011-2012 with the participation of football hooligans were supported by right-wing parliamentarians and public figures which confirmed highly problematic relationship between the anti-democratic extreme right and elements of the parliamentary conservative right (Pankowski, Kornak, 2013, pp. 166-167).

Also, some of the non-governmental organizations started their activities like the Institute for Legal Culture Ordo Iuris, that was created in 2013 by the Association of Christian Culture Fr. Piotr Skarga. This association resembles the think-tank of the legal practitioners and professors, who defend the constitution and advocate the traditional values. They also oppose 'sex education' in schools, overtly oppose the abortions, motivating it as a 'pro-life clauses', as well as advocate for the Polish Catholic identity (Cipek, Laskowicz, 2018, pp. 162-163).

Other examples for such organizations that have similar objectives and nature are The Mom and Dad Foundation (from 2010), Foundation Pro-Right to Life, The Centre for Supporting Initiatives for Life and Family, Catholic Professional Associations.

Looking back at these distinct three stages of the far-right extremists' mobilization we may see that their ideas and values have not changed much, only the types and scale of their actions have been increasing, taking up more and more people. The rhetoric of these movements has been initially anti-European, as they are completely antagonistic to the liberal democratic postulates, on which the basic EU Treaty is built. It is obvious, that the Union's aspiration 'to combat discrimination based on sex, racial or ethnic origin, religion or belief, disability, age or sexual orientation' will never be attained by the society, that manifests against LGBT+ community and women's right for abortion.

The agenda of these groups has clearly emerged from the growing uncertainty connected to the European integration. Having its roots from interwar period, extreme right has always put Polish independence on the first place, and by independence they mean not only sovereign state, but nationalism and isolationism. Obviously, this point of view became an alternative for those people, who did not want the EU accession and who saw Poland great on its own. That is why, the trend that can be observed is that shift of far-right political powers once being marginalized and scanty to growing big and having influence on civil society and political powers by the time of the presidential elections of 2015, when the PiS candidate Andrzej Duda won and then has been re-elected in 2020. 


\section{Current Eurosceptic political powers}

Since 2015, the party Law and Justice (Prawo i Sprawiedliwość, PiS) in Poland have taken over the power in government and engineered a revolt against the post1989 'liberal consensus'. By its ideology the party is a right-wing national-conservative, which does not fall into the discourse of the article, but some of the actions taken by the government exposed the binding with the far-right extremist groups and their support for them in different ways.

First of all, the electoral winning of PiS coincides with the refugee crisis in Europe, which reveale $\mathrm{d}$ xenophobic and nationalistic direction of the new Polish government. Poland is reluctant to accept some EU policies and proposals for joint actions. One of them was the creation of a common European Union migration policy, as well as opposition to mandatory quotas in the refugee relocation programme proposed by the EU in 2016 (Styczyńska, 2018, p. 75).

When the War in Syria erupted in 2014 and refugees started to flee from their countries, Europe, however mostly Germany, was eager to help and host the migrants. When the refugee crisis reached its peak in 2015, such states as Italy started to appeal to some effective solutions like the redistribution of the migrants, that were piling up in states like Italy, Greece, etc. In this case each member state of the EU was supposed to take some number of the refugees, that was calculated on the base of population and wealth of the country. Yet, the solution was rejected by Visegrad countries and Austria and because of that the European Commission announced financial penalties for those countries that fail to meet their designated quota of refugees. The Polish government consistently refused to satisfy this requirement and criticized the relocation programme. They grounded their decision by Poland's engagement in helping refugees from war-affected areas in Ukraine and fear of Islamization of Catholic Poland. In 2015, Jarosław Kaczyński claimed that Poland 'can't' accept any refugees because 'they could spread infectious diseases (Styczyńska, 2018, pp. 76-77).

The Polish populist radical right parties activated at that time and used this crisis to promote their rhetoric. Among them are Congress of the New Right (Kongres Nowej Prawicy - KNP), which won four seats in the European Parliament elections of 2014 and is the only openly Euro-reject party in Poland, Kukiz'15, which gained $8.81 \%$ of votes in the 2015 parliamentary election (cooperating with the far-right National Movement). The party claims that Islam is a danger to the cultural (Catholic) Polish identity, and calls asylum seekers 'culturally foreign'. Kukiz'15 is calling for a referendum on the refugee quotas that the EC proposed to introduce in 2015 (Styczyńska, 2018, pp. 78-79).

Analysing the radical right, it is important to emphasise the characteristics that distinguish it from the extreme right. Above all, the radical right criticises the existing democratic system; it is not anti-system as such, though, as it operates within the system and accepts its rules. Radical-right parties are usually anti-European and oppose the trends of modernization ..., the radical right is also characterized by aversion to individualism, as well as to upholding human rights (and especially minority rights). The radical right is characterized by nationalism and xenophobia, and also places an emphasis on law and order, in order to construct a monocultural state.' Here the fact, 
that Poland is extremely homogeneous in terms of ethnic division, right-wing parties see immigrants, people of a different religion or value system as enemies (Styczyńska, 2018, pp. 78-79).

Donald Tusk, former EU Council president and former Polish prime minister said: "We [Poland] are leaving the EU step by step. It's not an exaggeration. This departs from all the norms on which the European Union is built". However, he also added "I do not think that in the foreseeable future anyone would dare to publicly declare leading Poland out of the EU ... Rather, the danger is that Poland becomes part of a procession of lunatics who do not want to leave the EU, do not want the EU to shatter, but more or less consciously are doing everything so that the EU is weakened" ("The Guardian", 2020).

However, the latest events showed, that some candidates of the presidential elections 2020 dared to say so, as some of them were openly claiming the need of the Polexit during the campaign and debates. One of the candidates is Stanisław Żóttek, who is the leader of the party with pretentious name - PolEXIT, as well as the New Right party. The official site of the party declares: "For a strong Poland in Europe we must depend solely on ourselves - the Poles. That is why Germany or France today impose on us such laws that limit the development of Poland...". As an example of EU limitations, they give "... fees on our carbon footprint resulting in a drastic rise in electricity prices in the country" (PartiaPolEXIT, 2020), that is famous European Green Deal, to which Poland was reluctant to sign up. It includes various aspects, which are mainly aimed at enhancement of the EU's natural capital, and protection from environment-related risks and impacts. The deal closely connected to one of the United Nation's 2030 Agenda and the sustainable development goals (The European Green Deal, 2019).

The important question here whether Poland will really benefit from exiting the EU. So many efforts have been made for the accession and now Poland, living up and rebuilding on the EU funds, wants to be more independent, saying in the Donald Trump's style 'Poland first'. However, it is questionable whether Poland is in the position where it can dictate its own conditions and whether Poland needs EU more than EU needs it. Strategic geopolitical position of Poland is the reason of US friendly relations and recent visa regime elimination. Nevertheless, is it worth spoiling the relations with the neighbors and strengthening them with the remote partner? We will get the answers with time. Especially during the current difficult epidemiological crisis of COVID-19 Poland is unlikely to do any moves towards breaking the relations with the EU, as the EU support in terms of medical and economic aid is huge now and will be significant when the crisis ends and there will be the need for restoration of the economy (European Commission official site, 2020).

\section{Eurosceptic civil organizations and movements nowadays}

Far-right politics inevitably are coming from the civil society formations, so it is no wonder that far-right extremist movement in Poland is built up and visible.

All-Polish Youth is one of the most prominent civil organizations, which declares an ambition of being the National Movement. As we might understand from its title, 
it is mainly composed of young people and as their general idea they proclaim combination of traditional values with modern patriotism, creating the 'interesting alternative to the inaction'. At the same time, right among their main goals and ideas it is mentioned, that they have been reporting on the negative aspects of EU integration and that they oppose further bureaucratisation of the EU (Młodzież Wszechpolska official site, 2021).

This organization consciously work with the young people, who do not necessarily have their own mature opinion and whose youth maximalism might be easily manipulated and transformed into aggressive actions. Its history goes back to an extreme nationalist organisation of the same name active in the pre-war period. The original MW was responsible for numerous attacks on Jewish students in the years before the Second World War. It was re-launched by Roman Giertych in December 1989 and soon came to serve as a youth group for the re-formed National Party (Stronnictwo Narodowe, SN) and, since 2001, for the LPR (Pankowski, 2012, p. 3).

Recently, All-Polish Youth was engaged in the terrific scandal and murder of Gdansk mayor Paweł Adamowicz in 2019, known as a supporter of gay rights and the rights of migrants in the country. The attack took place at the nation's largest charity event, when a young man burst onto the stage and stabbed Mr. Adamowicz several times, including in the heart. Earlier in 2018 All-Polish Youth, issued fake death certificates for 11 liberal politicians, mostly associated with Civic Platform, including Mr. Adamowicz. Public voices say, that Mayor Adamowicz was a leading voice of opposition against far-right extremism, so his was an attack not just on the mayor, but on the very value of tolerance ("The New York Times", 2019). Currently, after two years, the investigation of this murder is being prolongated due to the weird circumstances, while the application of the opposition to the Minister of Justice to give any clarification has been blocked by PiS (Portal Miasta Gdanska, 2021). This situation causes serious doubts on the justice and judiciary in the country, especially that judicial reforms have been the issue since 2015, as they continuously do not comply with EU law and infringe a number of provisions (Eucrim, 2021).

National Radical Camp is another prominent far-right extremist organization, which often refers to at least three groups that are fascist, far-right and ultranationalist Polish organizations. Their official statement says: "We are a social movement bringing together young Poles who are close to such values as God, honor, motherland, family, tradition and friendship". Also, it is mentioned that they are not a political party, because they are "not interested in participating in the oligarchic parliamentary games" (Obóz Narodowo-Radykalny official site, 2021).

What is more, their official page contains such offensive clauses like 'leftist propaganda', 'rebirth of catholic values' and surveys of Polish opinion of immigration of Ukrainians. All the articles of its main declaration covertly oppose the EU integration, as it includes such ideas as Poland for Poles, A nation of the highest earthly value, and all other clauses, that appeal only to a nation, that is clearly exclusively Polish.

What is really alarming is that such organizations gain their power and impact on the political level and get the support from the government. In Wrocław, Tomasz Greniuch, an activist of the National Radical Camp has been appointed to head the local branch of the state-sponsored Institute of National Memory. Greniuch was charged 
with investigating the crimes committed during the German occupation of Poland and under Communist rule. The appointment caused public outrage and Greniuch had to resign shortly, but the fact stays unchanged - Polish government is linked to such groups (Open Democracy, 2021).

Under the PiS government, several institutions have already been established to serve the purposes of spreading the illiberal nationalistic ideas: for example, the Pilecki Institute (Instytut Pileckiego) (2017), the Institute of the Legacy of Solidarity (Instytut Dziedzictwa Solidarności) (2019), the Institute for Legacy of Polish National Thought (Instytut Dziedzictwa Myśli Narodowej) (2020) and others. On the contrary, in 2016 the Council for combating racial discrimination, xenophobia and related intolerance (Rada do spraw Przeciwdziałania Dyskryminacji Rasowej, Ksenofobii i związanej z nimi Nietolerancji) has been terminated by the government, motivating that by its uselessness (RPO, 2016).

It is hard to extract and analyze the sociological data on the supporters of the contemporary extreme right in Poland, as formally there is no political power in parliament supporting it. The closest by its values is Konfederacja KORWiN, that gained 5.1\% (Statista, 2021). Formally, PiS avoids describing itself as being far-right or having any connections to it, but during last fifteen years we observe how PiS deploys far-right language and rhetoric. However, PiS, that has $33.6 \%$ in the parliament and seemingly shows full support of Catholic fundamentalism, traditionalist views on family and gender roles, anti LGBT and homophobia, anti-Semitism and historical debates on nationalist narrative, anti-Russian and anti-European rhetoric. All of these attract two main groups of supporters and consequently electorate - elderly people who tend to stick to religious and traditional values, and whose main priority is stability, and youth (mainly from rural areas), who encounter difficulties with earning for living and access to the job market (Pankowski, 2012, pp. 7-8).

\section{Last parliamentary and presidential elections 2019-2020 as a reflection of the social trends}

Polish parliamentary elections of 2019 resulted in continuity of the incumbent PiS party-coalition, which looked like triumph for one and the total disappointment of others. As a result, PiS controls 235 out of 460 parliamentary seats $-51.1 \%$. That seems to be astonishing, as during previous five years PiS had been implementing the serious of illiberal and unlawful reforms, gaining a lot of controversy and engaging into the open conflict with the EU authorities. Nevertheless, this election has mobilized the highest proportion of eligible voters and witnessed the lowest 'wasted votes' indicator ever in the history of elections in Poland (Markowski, 2020).

However, even though PiS won the majority in the Lower House, it lost the majority in the Senate, which made the situation more difficult to cope with. Of course such results were undesirable for PiS and that is why they were trying to challenge it several times, as well as tried to bribe several senators from Koalicja Obywatelska party, both unsuccessful. For now PiS conducts already started direction and does not seem to change it, maybe only nominally, for the sake of gaining the electoral support. 
Nevertheless, Polish citizens remain very positive about the EU as it is visible from the graph below and the trend is that the number of the EU integration opponents only decreases during the time of PiS government and Andrzej Duda office.

Fig. 2. Support for European Union membership in Poland from 2014 to 2020

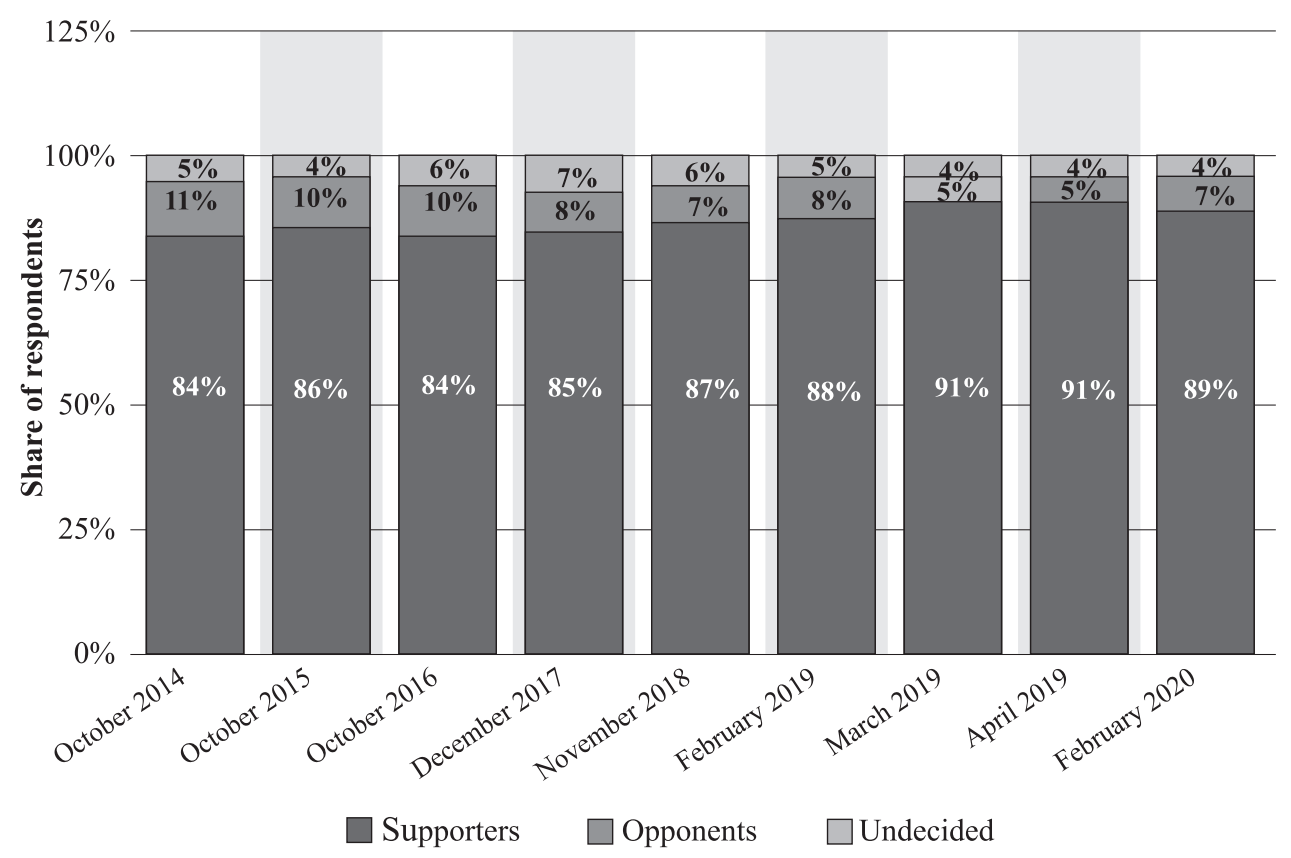

Source: https:/www.statista.com/statistics/957570/poland-attitude-towards-eu-membership/, 15.06.2021.

A lot was expected from the presidential elections of 2020, as the Polish president has veto powers which can effectively block legislation adopted by the Lower House, but the circumstances resulted into the opposite results. Year 2020 started with the difficult situation in all spheres of life due to the COVID-19 pandemic and presidential elections could also been postponed, as the social focus has been completely displaced and the financial and administrative resources would rather be spent on the fight with the virus.

Poland during the COVID-19 pandemic was unequivocally recognized by lawyers as dangerous legal chaos, the effects of which continue to this day. The traditional way of elections would mean the gathering of people of polling stations, which would inevitably pose threat to their health and wellbeing. Despite this, the ruling coalition (Zjednoczona Prawica), which is dominant in the Sejm, decided for the option of holding the electionson the original date, adopting a special law as the legal basis for their organization one month before the elections. It soon turned out that it was impossible to hold the presidential elections on time for organizational reasons and that there were controversies related to the leakage of printed and secured voting cards (the Polish PostOffice received the list of voters from the Ministry of Digitalisation without a legal basis, containing their personal data) (Human Rights Review, No. 3, vol. 2, July-September 2020). 
Rafał Trzaskowski had initially the huge support and was considered to be a very prosperous candidate - he would be the winner of the presidential election, gaining 325 electoral votes, while Andrzej Duda would receive 167 electoral votes. In fact, Andrzej Duda won in direct voting with an advantage of about 422 thousand votes over the opponent. The differences in the results of direct and electoral voting are a simple result of Andrzej Duda's high victory in the provinces where he won the majority of votes. In four voivodships it obtained over $60 \%$, in Małopolskie $59.65 \%$ and only in Łódzkie 54.46\%. Rafał Trzaskowski won in ten voivodeships, but he did not exceed the $60 \%$ threshold in any of them and in six of the voivodeships he won, he won with a vote difference of less than 10\% (Wendt, Bógdał-Brzezińska, 2020).

The landscape of the supporters of Andrzej Duda shows already known familiar composition of southern and eastern small cities and rural population which are most likely affected by the populist propaganda that is actively used by PiS (TVN24, 2020). Also, age composition shows that young people preferred Trzaskowski, while elderly people voted for Duda (TVP, 2020).

Unfortunately, 2020 presidential elections demonstrated no positive changes in the Polish society, but rather broader and deeper polarization and radicalization, which will likely translate into some more serious anti-EU trends. Some of the international independent reports are pounding the alarm on the disturbing situation in the country, seriously questioning whether Poland is going in the right direction, considering serious issues with judiciary, freedom of speech, women's and minorities' rights, etc. (World Report, 2021). Tightening of the law on reproductive rights caused serious tensions in the society, people mobilized to join all-Polish Women's strike, but that did not affect the government's decision to almost totally ban abortions, so that even in case of severe illness or defect it will not be allowed (Amnesty International, 2020). The efforts of the right-wing groups to consolidate the system of power based on populism, the oligarchizing of the party elite and their support from conservative voters could actually result into some serious downshift in the quality of the democracy and rule of law in Poland. According to Freedom House Poland's National Democratic Governance accounted for 3.75 out of 7, comparing to 5.5 out of 7 in 2015 , as well as overall score of the country has dropped from 80 out of 100 in 2015 to 60 out of 100 in 2021 (Freedom House, 2021).

\section{Conclusions}

Paradoxically, Poland remains highly Eurooptimistic when it comes to the society surveys and heavily Eurosceptic in its politics and government. Unfortunately, all the actions of the present government drive Poland rather away from the EU, currently the Polish government joined Hungary in blocking the EU's $€ 1.8$ trillion budget and pandemic recovery fund. Moreover, with all this situation Poland seems to have forgotten that its economy has been rebuild on the EU funds and now remains heavily dependent on it.

The rise of populism and nationalism is not unique to Poland, as this trend is emerging globally as a response to the inequality caused by the neoliberal politics and 
globalized market economy. However, the Polish path differs due to many important aspects of Polish history, identity, and national idea. The presence of the far-right extremist groups which are highly attractive for the youth, enhanced role of the Catholic church in Polish society and strong national idea of cultural independence play crucial role in Eurosceptic movement. Consequently, populist political powers find it easy to exploit in their interests to gain electoral support throughout the majority of the voting population.

The discussion on Polexit remains open, but rather still theoretical for the moment being, as Polish government's ambition for the entirely independent Polish nation from all external issues is simply not attainable in the context of the globalized world. This rather poses a serious task for political elites of Poland of integrating those who have not been benefiting from the neoliberal order, but evidently the populist rhetoric is not doing any help, if only make it worse.

\section{Bibliography}

Amnesty International, Poland 2020, https:/www.amnesty.org/en/location/europe-and-central-asia/ poland/report-poland/, 15.10.2021.

Bill S., Stanley B. (2020), Whose Poland is it to be? PiS and the struggle between monism and pluralism, "East European Politics", 36:3, pp. 378-394, https://doi.org/10.1080/21599165.202 0.1787161 .

Cipek T., Lacković S. (2019), Civil Society and the Rise of the Radical Right in Poland, "Politička misao", 56 (3-4), pp. 153-176, https://doi.org/10.20901/pm.56.3-4.07.

Eucrim - The European Criminal Law Associations' Forum, Poland: Rule-of-Law Developments April-June 2021 - eucrim accessed 12.10.2021.

European Commission Coronavirus response, https://ec.europa.eu/info/live-work-travel-eu/coronavirus-response_en, 16.06.2021.

Freedom House, Poland, https://freedomhouse.org/country/poland/nations-transit/2015, 15.10.2021.

GMF, The Conservative-Liberal Clash Reshaping Poland's Civil Society, https://www.gmfus.org/ blog/2020/03/10/conservative-liberal-clash-reshaping-polands-civil-society, 17.06.2021.

Golder M. (2016), Far Right Parties in Europe, "Annual Review of Political Science” 19: 1, pp. 477-497, https://doi.org/10.1146/annurev-polisci-042814-012441.

http://www.cbos.pl/SPISKOM.POL/2004/K_044_04.PDF, 10.10.2021.

Kalb D. (2009), Headlines of Nationalism, Subtexts of Class: Poland and Popular Paranoia, 1989-2009, “Anthropologica”, vol. 51, no. 2, pp. 289-300, Canadian Anthropology Society.

Kasprowicz D. (2015), The radical right in Poland - from the mainstream to the margins, Routledge.

Marcinkiewicz K., Stegmaier M. (2016), The parliamentary election in Poland, October 2015, Electoral Studies, http://dx.doi.org/10.1016/j.electstud.2016.01.004.

Młodzież Wszechpolska official site, https://mw.org.pl/, 16.06.2021.

Mudde C. (2000), The ideology of the extreme right, Manchester University Press, Manchester-New York.

Narkowicz K. (2018), 'Refugees Not Welcome Here': State, Church and Civil Society Responses to the Refugee Crisis in Poland, Int J Polit Cult Soc 31, pp. 357-373, https://doi.org/10.1007/ s10767-018-9287-9.

ONR official site, https://www.onr.com.pl/deklaracja-ideowa/, 15.06.2021. 
Open Democracy, From street to state: How radical nationalists gained power in Poland, https:// www.opendemocracy.net/en/countering-radical-right/street-state-how-radical-nationalists-gained-power-poland/, 16.06.2021.

Ost D. (2018), Workers and the Radical Right in Poland, International Labor and Working-Class History, 93, pp. 113-124, doi: 10.1017/S0147547917000345.

Pankowski R. (2010), The Populist Radical Right in Poland, Routledge, London-New York.

Pankowski R. (2010), The Populist Radical Right in Poland: The Patriots (1st ed.), Routledge.

Pankowski R., Kornak M. (2013), Right-Wing Extremism in Europe, Poland, (eds.) R. Melzer, S. Serafin, Friedrich Ebert Stiftung Forum Berlin.

Płatek D., Płucienniczak P. (2017), Mobilizing on the Extreme Right in Poland: Marginalization, Institutionalization, and Radicalization, 10.2307/j.ctvw04jx2.16, 10.06.2021.

Płatek D., Płucienniczak P. (2016), Civil Society and Extreme-Right Collective Action in Poland 1990-2013, Revue d'études comparatives Est-Ouest, 47.

Politico, Polexit: 3 reasons why Poland will quit the EU and 3 why it won't, https://www.politico.eu/ article/polexit-poland-veto-kaczynski-morawiecki-polexit-brexit-eu/, 17.06.2021.

Public Opinion Research Center (CBOS) III 2004, Załamanie się optymizmu w myśleniu o efektach integracji z Unia Europejska,

Public Opinion Research Center (CBOS) VII 2000, Opinie o skutkach integracji z Unia Europejska i przebiegu negocjacji akcesyjnych, http://www.cbos.pl/SPISKOM.POL/2000/K_105_00. PDF, 10.10.2021.

Rodríguez-Aguilera de Prat C. (2013), Euroscepticism, Europhobia and Eurocriticism, Peter Lang S.A. International Academic Publishers, Brussels.

Ruth W., Khosravinik M., Mral B. (2013), Right-Wing Populism in Europe: Politics and Discourse, Bloomsbury Academic, London, http://dx.doi.org/10.5040/9781472544940.

Rzecznik Praw Obywatelskich, https://www.rpo.gov.pl/pl/content/wystapienie-do-mswia-oraz-ministra-cyfryzacji-ws-przeciwdzialania-mowie-nienawisci, 17.06.2021.

Stanley B. (2020), Counter-Elite Populism and Civil Society in Poland: PiS's Strategies of Elite Replacement, "East European Politics and Societies and Cultures", vol. XX, no. X Month 201X 1-23, Sage Publications.

Statista, Public support for political parties in Poland as of July 2021, https://www.statista.com/ statistics/1094949/poland-support-for-political-parties/, 12.10.2021.

Statista, Support for European Union membership in Poland from 2014 to 2020, https://www.statista. $\mathrm{com} /$ statistics/957570/poland-attitude-towards-eu-membership/, 15.06.2021.

Styczyńska N. (2018), Refugees Not Welcome. The Populist Radical Right in Poland and the Migration Crisis, in: Visions and Revisions of Europe, eds. K. Czerska-Shaw, M. Galent, B. Gierat-Bieroń, Universitätsverlag Göttingen.

Swindal M. G. (2011), Ideology and Social Position in Poland: The Determinants of Voting for the Right 1991-2005, "Social Science Quarterly", vol. 92, no. 1, Southwestern Social Science Association.

Taggart P., Szczerbiak A. (2002), The Party Politics of Euroscepticism in EU Member and Candidate States, Turin.

The European Green Deal, 2019, https://ec.europa.eu/info/sites/default/files/european-green-deal-communication_en.pdf, 08.06.2021.

“The Guardian" (2020), Poland's leadership doesn't need 'Polexit' - it can undermine the EU from within, https://www.theguardian.com/world/commentisfree/2020/mar/10/poland-polexit-eurightwing-law-justice-party-judiciary, 10.06.2021.

“The New York Times", Polish Mayor Dies After Being Stabbed Onstage at Charity Event, https:// www.nytimes.com/2019/01/14/world/europe/pawel-adamowicz-gdansk-mayor-dead.html, 16.06.2021. 
TVN24, Andrzej Duda wygrat tylko na wsi, https://tvn24.p1/wybory-prezydenckie-2020/wyniki-wyborow-prezydenckich-2020-sondaz-jak-glosowano-na-wsi-i-miastach-4635340, 13.10.2021.

TVP, Jak głosowali Polacy ze względu na wiek? [STATYSTYKI], https://www.tvp.info/48941256/ wybory-prezydenckie-2020-wyniki-exit-poll-badanie-sondaz-kto-wygral-jak-polacyglosowali-ze-wzgledu-na-wiek-kto-wygral-w-poszczegolnej-kategorii-wiekowej-analiza-wieszwiecej, 13.10.2021.

Wendt A. J., Bógdał-Brzezińska A. (2020), Presidential Elections in Poland and the United States and Democracy, "Revista Română de Geografie Politică", 22(2), pp. 61-70, https://doi. org/10.30892/rrgp.222101-336.

World Report 2021, Poland, https://www.hrw.org/world-report/2021/country-chapters/poland, 15.10.2021.

\section{Summary}

Far-right extremist groups in Poland have undergone the substantive evolution over the course of last thirty years - from being marginalized, small in number group to being one of the most developed and numerous movements in civil society, as well as on the political landscape. The article examines the history of this movement, its stages of development and demonstrates how pivotal is the role of far-right groups in Euroscepticism in Poland.

Key words: Euroscepticism, far-right, extremism, populism, civil society, Polexit

\section{Struktura ruchu eurosceptycznego w Polsce - skrajnie prawicowi polityczni i obywatelscy ekstremiści}

\section{Streszczenie}

Skrajnie prawicowe grupy ekstremistyczne w Polsce przeszły w ciągu ostatnich trzydziestu lat znaczącą ewolucję - od marginalnej, niewielkiej liczebnie grupy do jednego z najbardziej rozwiniętych i licznych ruchów w społeczeństwie obywatelskim, a także w krajobrazie politycznym. Artykuł bada historię tego ruchu, jego etapy rozwoju i pokazuje, jak kluczową rolę w eurosceptycyzmie w Polsce odgrywają skrajnie prawicowe grupy.

Słowa kluczowe: eurosceptycyzm, skrajna prawica, ekstremizm, populizm, społeczeństwo obywatelskie, Polexit 
